\title{
Prevalensi dan Karakteristik Buta Warna pada Populasi Urban di Jakarta
}

\author{
Syntia Nusanti ${ }^{1}$, M. Sidik ${ }^{1}$ \\ ${ }^{1}$ Neuro-Ophthalmology Division, Departement of Ophthalmology Universitas Indonesia \\ Cipto Mangunkusumo Hospital, Jakarta \\ E-mail: syntia_nusanti@hotmail.com
}

\begin{abstract}
ABSTRAK
Tujuan: Mengetahui prevalensi buta warna di masyarakat populasi urban di Jakarta Metodologi: Penelitian ini merupakan bagian dari Urban Eye Health Study. Dilakukan pemeriksaan buta warna dengan menggunakan ishihara pada seluruh pasien anak dan dewasa yang memiliki visus $6 / 6$. Bila terdapat jawaban salah dari pemeriksaan ishihara, pemeriksaan buta warna dilanjutkan dengan menggunakan Farnsworth Munsell Hue D 15 kemudian diberikan kuesioner. Buta warna akan diklasifikasikan menjadi buta warna kongenital dan didapat.

Hasil: Jumlah total responden anak yang memenuhi kriteria inklusi untuk pemeriksaan buta warna adalah 435 dengan rentang usia 6-16 tahun. Dari jumlah tersebut didapatkan 5,97\% menderita buta warna. Sedangkan jumlah responden dewasa (41-77 tahun) yang memenuhi kriteria inklusi adalah 1040 dengan 3,26\% responden dewasa menderita buta warna. Seratus persen responden anak mengalami buta warna kongenital. Delapan puluh delapan koma dua puluh empat persen responden dewasa menderita buta warna kongenital sedangkan sisanya sebesar $11,76 \%$ menderita buta warna didapat.
\end{abstract}

Kesimpulan: Prevalensi penderita buta warna kongenital pada penelitian ini adalah 3,79\%, pada pasien dewasa sebanyak $88,24 \%$ dan pada anak $100 \%$ dari pasien yang buta warna.

Kata Kunci: prevalensi, Ishihara, Farnsworth Munsell Hue D 15, buta warna kongenital, buta warna didapat

\begin{abstract}
Purpose: To report the prevalence of color blindness in urban population in Jakarta

Methods: This study is a part of the Urban Eye Health Study. Color vision examination was performed using Ishihara on adult and pediatric subjects with 6/6 vision. If incorrect reading was present, the examination was later continued by using Farnsworth Munsell Hue D 15, then proceeded with completing questionnaire.

Results: The pediatric respondents in this study was 435 (6-16 years old). From that number of subjects, 5,97\% of children had color blind. Meanwhile, the adult respondents (41-77 years old) in this study was 1040 with 3.26\% of respondents had color blind. There were $100 \%$ of pediatric respondents diagnosed with congenital color blindness. Eighty-eight point twenty
\end{abstract}


four percent of adult respondents were diagnosed with congenital color blindness while the remaining $11.76 \%$ were diagnosed with acquired color blindness.

Conclusions: The prevalence of congenital color blindness in this study was 3,79\%, as much as $88,24 \%$ from the adult group and $100 \%$ from the pediatric group.

Keywords: Prevalence, color vision, Ishihara, Farnsworth Munsell Hue D 15, congenital color blind, acquired color blind,

\section{PENDAHULUAN}

$\mathrm{P}$ revalensi buta warna di seluruh dunia berkisar antara 2-5 \% dengan perbandingan antara laki laki dan perempuan adalah $3: 1$. Sampai saat ini beluh pernah ada data mengenai prevalensi buta warna di Indonesia baik tipe kongenital maupun yang didapat.

Buta warna kongenital disebabkan karena abnormalitias kromosom yang mengatur fotopigmen sel kerucut, dan dapat diklasifikasikan menjadi monokromat, dikromat dan anomalous trikromat. Pada buta warna kongenital, penderita tidak dapat membedakan panjang gelombang dan hanya mampu melihat satu komponen warna. Sedangkan buta warna kongenital dikromat dan anomalous trikromat diklasifikasikan berdasarkan fotopigmen sel kerucut yang terdampak. Pada buta warna kongenital dikromat, terdapat satu fotopigmen sel kerucut yang hilang, sehingga penderita hanya mempunyai dua fotopigmen kerucut yang berfungsi, sehingga penderita hanya dapat melihat dua komponen warna. Sedangkan pada anomalous trikromat, penderita memiliki tiga fotopigmen sel kerucut dan dapat membedakan tiga komponen warna. Ketiga komponen tersebut masih dapat digunakan untuk menggabungkan warna, namun intensitas warna terlihat lebih rendah. ${ }^{(1,2)}$ Buta warna didapat dapat disebabkan karena kelainan pada saraf optik ataupun retina. Kelainan pada saraf optik dilaporkan berdampak pada diskriminasi warna merah atau hijau, sedangkan kelainan retina menyebabkan gangguan diskriminasi warna biru/kuning. ${ }^{(3)}$

Keadaan buta warna seringkali memberikan gangguan pada penderitanya, baik dalam kegiatan sehari-hari maupun saat penderita akan menempuh pendidikan ke tingkat yang lebih tinggi maupun untuk melamar pekerjaan jenis tertentu. Oleh karena itu, dibutuhkan skrining buta warna pada seluruh lapisan masyarakat. Pemeriksaan yang sering dilakukan pada skrining buta warna adalah dengan menggunakan pseudoisochromatic plate (Ishihara), karena pemeriksaan ini dapat menilai kelainan pengelihatan warna dengan cepat dan tepat. Walaupun plate Ishihara didesain untuk mendeteksi buta warna kongenital, total jumlah plate yang salah dapat membantu memperkirakan buta warna didapat.

Penelitian ini merupakan salah satu bagian dari urban eye health study, yaitu suatu penelitian epidemiologi mata yang dilakukan di masyarakat urban di Jakarta. Tujuan penelitian ini adalah untuk menjabarkan angka prevalensi buta warna kongenital maupun didapat baik pada usia dewasa maupun anak-anak serta karakteristiknya. Selain itu, pada penelitian ini juga mencoba untuk mencari sikap dan pengetahuan penderita terhadap keadaan buta warna yang diderita. Hal ini diharapkan dapat meningkatkan kesadaran dan pengetahuan masyarakat, karena penderita buta warna hanya dapat bekerja dibeberapa sektor mata pencaharian. Sehingga dengan mengetahui keadaannya, penderita dapat mempertimbangkan pekerjaan yang sesuai

\section{METODE PENELITIAN}

Penelitian ini menggunakan metode deskriptif dengan data primer yang diambil dari hasil pemeriksaan langsung pada 
masyarakat urban Jakarta yang memenuhi kriteria inklusi. Sampel diambil menggunakan metode consecutive sampling pada populasi masyarakat di Puskesmas Kampung Makasar dan Puskesmas Kebon Pala, Jakarta Timur, periode 19 - 29 Juli 2008. Dilakukan pemeriksaan buta warna dengan menggunakan Ishihara 14 plate pada semua subjek yang memiliki visus 6/6. Apabila pada hasil pemeriksaan ishihara didapatkan kesalahan sebanyak 2 plate, pemeriksaan dilanjutkan menggunakan FarnsworthMunsell Hue D-15, kemudian sampel diminta untuk mengisi kuesioner.

Penelitian ini dilakukan pada 2 kelompok, yaitu kelompok dewasa usia 41 - 77 tahun dan kelompok anak usia 6 - 16 tahun. Kriteria inklusi pada kelompok dewasa maupun kelompok anak diantaranya adalah mempunyai visus 6/6 dengan atau tanpa koreksi (pada masingmasing mata) dan bila hanya satu mata yang dapat mencapai visus $6 / 6$, hanya dilakukan pemeriksaan pada satu mata tersebut.

Setelah subjek memenuhi kriteria inklusi, dilakukan pemeriksaan buta warna yang diawali dengan menggunakan Ishihara pada kedua mata. Apabila kesalahan hanya pada 1 panel, maka pasien dinyatakan normal atau tidak memiliki buta warna. Namun, bila didapatkan kesalahan pada 2 panel atau lebih pada subjek dewasa maka dilanjutkan pemeriksaan dengan Farnsworth-Munsell Hue D 15. Pemeriksaan ini dilakukan pada masingmasing mata sebanyak 3 kali. Setiap kali selesai dilakukan pemeriksaan FarnworthMunsell Hue D 15, beri waktu pada subjek untuk mengoreksi panel warna, lalu dilanjutkan dengan mengisi kuesioner. Pada subjek anak, bila didapatkan kesalahan pada Ishihara sebanyak 2 panel atau lebih, pemeriksaan dilanjutkan dengan pengisian kuesioner oleh orang tua / wali. Jumlah dan nomor panel yang salah dicatat pada kuesioner tersebut. Kuesioner yang digunakan pada subjek dewasa maupun anak adalah sama.
Pada penelitian ini terdapat beberapa definisi operasional, yaitu: buta warna kongenital, buta warna didapat, buta warna parsial, dan buta warna total. Buta warna kongenital adalah terdapat kelainan pada dua mata yang simetris dan/atau terdapat riwayat keluarga sedarah yang menderita buta warna. Buta warna didapat adalah terdapat kelainan pada satu atau dua mata yang tidak simetris. Buta warna parsial adalah terdapat hasil interpretasi pemeriksaan ishihara yang menyatakan buta warna parsial, yaitu bila hasil pemeriksaan Ishihara pada responden terjadi kesalahan pada 2 plate, yaitu diantara plate nomor 6 sampai 8 dan 10 sampai 11. Sedangkan buta warna total adalah bila didapatkan hasil interpretasi pemeriksaan ishihara menyatakan buta warna total, yaitu bila subjek sudah melakukan kesalahan pada plate pertama Ishihara.

Data yang dikumpulkan adalah nomor subjek, nama subjek, umur, jenis kelamin, hasil pemeriksaan buta warna dengan Ishihara, dan hasil kuesioner. Data kemudian diolah dengan menggunakan SPSS13.

\section{HASIL}

Jumlah total responden anak usia 616 tahun adalah 479 sedangkan anak dengan visus dengan koreksi maupun tanpa koreksi mencapai 6/6 adalah 435 anak, sehingga anak yang memenuhi kriteria inklusi untuk pemeriksaan buta warna adalah 435. Dari jumlah tersebut didapatkan 5,97\% anak menderita buta warna. Sedangkan jumlah responden dewasa yang memenuhi kriteria inklusi adalah 1040 dengan 3,26\% responden menderita buta warna. Prevalensi penderita buta warna kongenital pada penelitian ini adalah $3,79 \%$. 


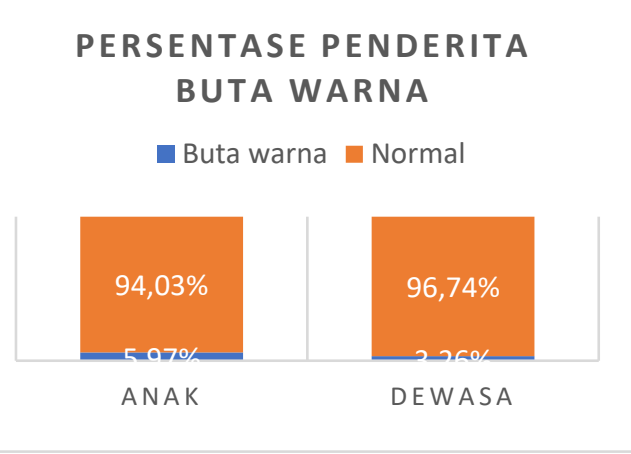

Gambar 1. Presentase penderita buta warna berdasarkan kelompok usia

Usia responden anak 6-16 tahun (mean 10,31) dan 76,9\% berjenis kelamin laki-laki sedangkan responden dewasa antara 41-77 tahun (mean 53,26) dengan $91,1 \%$ berjenis kelamin laki-laki.

Seratus persen responden anak mengalami buta warna kongenital, dimana $30,7 \%$ menderita buta warna total dan $69,23 \%$ menderita buta warna parsial.

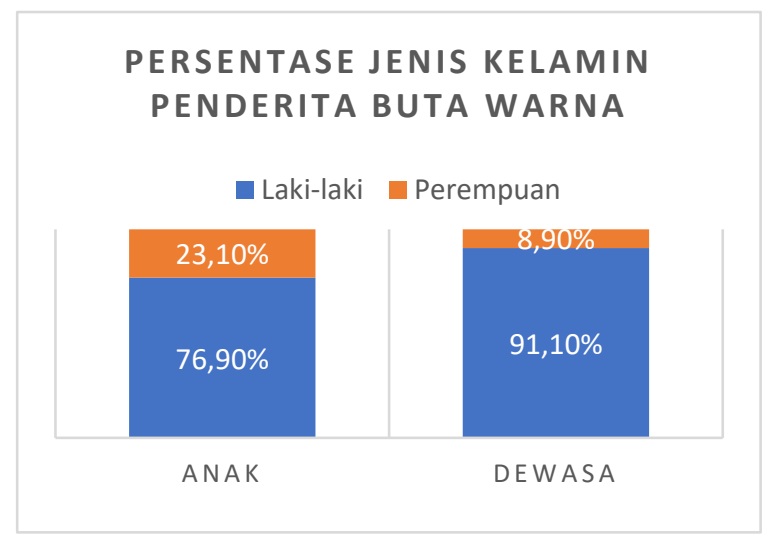

Gambar 2. Presentase jenis kelamin penderita buta warna berdasarkan kelompok usia

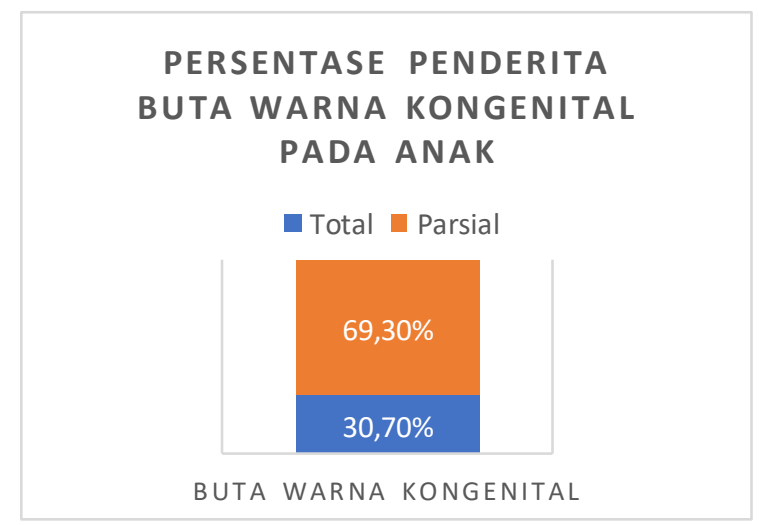

Gambar 3. Presentase penderita buta warna kongenital pada anak
Dari orang tua responden anak, hanya didapatkan 3 orang tua sudah mengetahui bahwa anaknya menderita buta warna; 1 karena anak sudah pernah diperiksa sebelumnya dan riwayat buta warna di keluarga (saudara kandung), dan 2 karena mengalami kesulitan dalam kehidupan sehari-hari maupun aktivitas sekolah.

Terdapat $88,24 \%$ responden dewasa yang mengalami buta warna kongenital. Empat orang $(11,76 \%)$ responden dewasa menderita buta warna didapat, tiga orang dengan riwayat penggunaan alkohol, satu orang dengan riwayat pengobatan etambutol. Sepuluh responden dewasa sudah mengetahui kondisi buta warna yang dimiliki karena sudah pernah dilakukan pemeriksaan sebelumnya dan setengahnya (5 responden) memiliki riwayat keluarga yang juga menderita buta warna. Enam responden mengaku sudah mengetahu dirinya buta warna tanpa pernah melalui pemeriksaan buta warna sebelumnya, setengahnya (3 responden) memiliki keluarga yang juga menderita buta warna. Satu orang responden tidak mengetahui jika dirinya menderita buta warna, namun memiliki saudara kandung yang juga menderita buta warna.

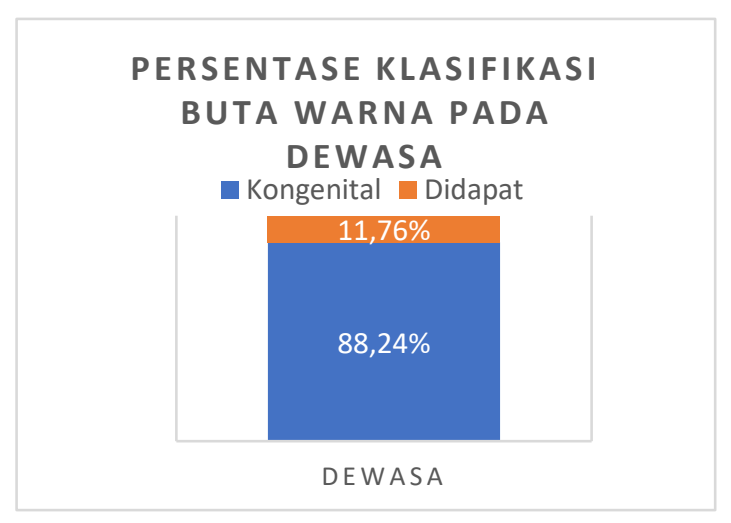

Gambar 4. Presentase klasifikasi buta warna pada dewasa 


\section{DISKUSI}

Berdasarkan survey besar yang dilakukan pada tahun 1852-1853 di Inggris didapatkan prevalensi buta warna pada masyarakat adalah sebesar 5,6\%, sedangkan pada survey besar di Australia pada 7700 responden pada tahun 1956 didapatkan buta warna kongenital pada laki-laki sebesar $2 \%$ sedangkan wanita sebesar $0,03 \% .^{(2,4)}$ Pada penelitian ini dengan jumlah responden sebesar 1475 responden didapatkan prevalensi buta warna kongenital sebesar 3,79\%.

Pada penelitian prospektif di India, terdapat $61(1,89 \%)$ dari 3259 anak usia sekolah (6-15 tahun) yang mengalami buta warna, dimana prevalensi anak laki-laki $(1.69 \%)$ lebih tinggi dibandingkan anak perempuan $(0.184 \%) .{ }^{(5)}$ Penelitian oleh Sushil et al pada 585 anak usia sekolah (1016 tahun) di area rural Nepal juga juga mendapatkan prevalensi buta warna yang lebih tinggi pada anak laki-laki, (5.12\%) dibandingkan anak perempuan sebesar $(2.56 \%) .{ }^{(6)}$ Sedangkan pada penelitian ini didapakan $25(5,97 \%)$ anak usia 6-16 tahun yang menderita buta warna baik berjenis kelamin laki-laki dan perempuan. Sebagian besar responden anak dan orangtuanya tidak mengetahui akan kondisi buta warna yang dimiliki. Hanya yang mengalami gangguan pada kehidupan sehari-hari, sudah pernah diperiksa sebelumnya, dan memiliki saudara kandung yang juga menderita buta warna yang sudah mengetahui kondisi buta warna yang diderita. Keadaan buta warna sebaiknya diketahui sejak dini agar anak-anak dapat beradaptasi dan dapat memilih pekerjaan yang sesuai dengan keadaan tersebut sehingga tidak menjadi hambatan di masa yang akan datang.

Sebuah penelitian di distrik Gilgit, Pakistan, menyatakan dari 995 orang dewasa terdapat 11 orang $(1.10 \%)$ yang mengalami buta warna parsial (merah dan hijau). Dari 11 orang tersebut semuanya berjenis kelamin laki-laki. ${ }^{(7)}$ Penelitian lainnya di area rural Iran mendapatkan prevalensi buta warna sebesar $13.39 \%$ dari
3132 responden, dengan persentase lakilaki $15.85 \%$ dan perempuan $12.96 \%$ dan kelompok usia terbanyak adalah $>60$ tahun $(20.93 \%)$ dan 46-60 tahun (20.53\%). ${ }^{(8)}$ Pada penelitian ini, dengan jumlah responden dewasa sebanyak 1040 didapatkan $3.26 \%$ responden menderita buta warna. Sebagian besar responden dewasa sudah mengetahui kondisi buta warna yang dimiliki karena sudah pernah melakukan pemeriksaan buta warna sebelumnya saat akan masuk kerja atau sekolah yang dahulu menjadi hambatan bagi responden untuk memasuki suatu sekolah atau melamar salah satu jenis pekerjaan. Enam orang responden sudah mengetahui mereka menderita buta warna tanpa pernah mengalami pemeriksaan buta warna sebelumnya karena memiliki saudara sekandung yang juga menderita buta warna dan mengalami gangguan pada kehidupan sehari-hari. $^{(9)}$

Dari responden dewasa yang mengalami buta warna teradapat $88,24 \%$ responden mengalami buta warna kongenital, $11,76 \%$ menderita buta warna didapat, yang faktor risikonya adalah konsumsi alkohol dan penggunaan etambutol. Konsumsi alkohol jangka panjang dalam jumlah berlebih dapat menyebabkan timbulnya kerusakan pada nervus optik yang terjadi secara bilateral meskipun kerusakan yang ditimbulkan tidak selalu simetris. Sehingga meskipun kelainan buta warna yang terjadi bilateral, derajat buta warna pada mata kanan dan kiri tidak simetris sehingga dapat dibedakan dengan buta warna kongenital ${ }^{(5,10)}$. Pada penelitian sebelumnya juga disebutkan bahwa 11 dari 16 peminum alkohol yang diperiksa dengan Farnsworth-Munsell 100 menderita buta warna. ${ }^{(1)}$ Studi lain mengenai efek samping terapi etambutol menunjukan sebanyak $8.6 \%$ pasien mengalami buta warna setelah minimal 2 bulan terapi. ${ }^{(12)}$

\section{KESIMPULAN}

Dari seluruh responden yang masuk kriteria inklusi, terdapat $5,97 \%$ responden 
anak yang menderita buta warna baik berjenis kelamin laki-laki dan perempuan. Sedangkan pada total responden dewasa yang memenuhi kriteria inklusi, sebanyak $3,26 \%$ responden menderita buta warna baik laki-laki maupun perempuan. Prevalensi penderita buta warna kongenital pada penelitian ini adalah $3,79 \%$, pada pasien dewasa sebanyak $88,24 \%$ dan pada anak sebanyak $100 \%$ dari pasien yang buta warna. Dari responden anak yang menderita buta warna kongenital, sebanyak $30,7 \%$ menderita buta warna total dan $69,23 \%$ menderita buta warna parsial. Faktor penyebab buta warna yang didapat pada responden dewasa pada penelitian ini antara lain konsumsi alkohol jangka panjang dan riwayat konsumsi etambutol.

Pada penelitian ini didapatkan responden anak yang lebih sedikit dari responden dewasa. Hal ini mungkin disebabkan karena waktu pengambilan sampel yang dilakukan pada hari masuk sekolah. Oleh karena itu, pada penelitian berikutnya dapat dipertimbangkan untuk pengambilan sampel pada hari libur sekolah. Selain itu karena pengambilan sampel untuk penelitian ini secara konsekutif, sehingga subjek yang didapat hanyalah subjek yang datang. Ada baiknya pada penelitian berikutnya pengambilan sampel dilakukan dengan mendatangi atau menjemput responden, sehingga sampel yang didapat akan lebih sesuai yang diinginkan.

\section{REFERENCES}

1. Hasrod N, Rubin A. Defects of colour vision: A review of congenital and acquired colour vision deficiencies. African Vis Eye Heal. 2016;75(1):1-6.

2. Birch J. Diagnosis of Defective Color Vision. 2nd ed. Oxford: Butterworth-heinemmann; 2001. 30-37 p.

3. Martin TJ, Corbett JJ. Practical Neuroophthalmology. McGraw Hill Education; 2013.

4. Hart M. Acquired Dyschromatopsias. Surv Ophthalmol. 1987;32(1).

5. Moudgil T. Prevalance of Colour Blindness in Children. Int J Med Dent Sci. 2016;5(2):1252.
6. Sushil K. Prevalence of Congenital Colour Vision Deficiency (CVD) in School Children of Bhaktapur, Nepal. Int J Med Sci Clin Invent. 2017;(August):8-11.

7. Woldeamanuel GG, Geta TG. Prevalence of color vision deficiency among school children in Wolkite, Southern Ethiopia. BMC Res Notes [Internet]. 2018;11(1):1-5. Available from: https://doi.org/10.1186/s13104-0183943-z

8. Gilgit D, Hussain I, Amir S. Prevalence of Color Vision defects ( CVD ) Among Adult Human. 2018;2(4):1-6.

9. Hashemi H, Khabazkhoob M, Pakzad R, Yekta A, Heravian J, Nabovati $P$, et al. The prevalence of color vision deficiency in the northeast of Iran. J Curr Ophthalmol. 2019;31(1):80-5.

10. Gegenfurtner KR, Kiper DC. Color vision. Annu Rev Neurosci. 2003;26:181-206.

11. Martins ICV da S, Souza G da S, Brasil A, Herculano AM, Lacerda EM da CB, Rodrigues AR, et al. Psychophysical Evaluation of Visual Functions of Ex-Alcoholic Subjects After Prolonged Abstinence. Front Neurosci. 2019;13(March):1-11.

12. Bandyopadhyay S, Banerjee S, Bandyopadhyay S, Shamantha M, Biswas S. A prospective evaluation of ocular toxicity in patients receiving ethambutol as antitubercular therapy. Sudan J Ophthalmol. 2020;12(1):12. 


\section{LAMPIRAN}

\section{LEMBAR PEMERIKSAAN COLOR VISION}

$\begin{array}{ll}\text { No Subjek } & : \\ \text { Nama } & : \\ \text { Usia } & :\end{array}$

Hasil pemeriksaan Ishihara :

(isi dengan no panel yang salah )

\section{Hasil pemeriksaan FM 15 Hue : (hanya untuk responden dewasa)}

OD

\begin{tabular}{|l|l|l|l|l|l|l|l|l|l|l|l|l|l|l|}
\hline $\mathbf{1}$ & & & & & & & & & & & & & & \\
\hline $\mathbf{1}$ & & & & & & & & & & & & & & \\
\hline $\mathbf{1}$ & & & & & & & & & & & & & & \\
\hline
\end{tabular}

OS

\begin{tabular}{|l|l|l|l|l|l|l|l|l|l|l|l|l|l|l|}
\hline $\mathbf{1}$ & & & & & & & & & & & & & & \\
\hline $\mathbf{1}$ & & & & & & & & & & & & & & \\
\hline $\mathbf{1}$ & & & & & & & & & & & & & & \\
\hline
\end{tabular}

Kuesioner :

1. Apakah anda/anak anda mengetahui bahwa anda/anak anda buta warna ?
a. ya, karena sudah diperiksa sebelumnya (lanjut ke dua)
b. ya, tahu sendiri (lanjut ke dua)
c. Tidak (lanjut ke 3)

2. Kapan anda tahu anda/anak anda buta warna ?.

3. Apakah anda/anak anda merasa terganggu dengan keadaan buta warna ini?
a) dalam hal sekolah
b) dalam pekerjaan maupun melamar pekerjaan
: ya
tidak
c) dalam kehidupan sehari-hari
: ya
tidak contoh :

4. Apakah ada saudara sedarah anda yang menderita buta warna?
a. ya
b. tidak
c. tidak tahu

5. Apakah pekerjaan anda sekarang ?.

6. Apakah ada riwayat pengunaan?

$\begin{array}{lll}\text { - Alkohol } & \text { ya } & \text { tidak } \\ \text { - Etambutol } & \text { ya } & \text { tidak } \\ \text { - Klorokuin } & \text { ya } & \text { tidak } \\ \text { - obat jantung } & \text { ya } & \operatorname{tidak}(\ldots \ldots \ldots \ldots \ldots \ldots \ldots \ldots \ldots \ldots \ldots \ldots \ldots \ldots \ldots \ldots \ldots \ldots \ldots \ldots \ldots \ldots \ldots \ldots \ldots \ldots \ldots \ldots \ldots \\ \text { - obat jangka panjang lainnya } & \text { ya } & \operatorname{tidak}(\ldots \ldots \ldots \ldots \ldots \\ \text { - Merokok } & \text { ya } & \text { tidak }\end{array}$

